\title{
A Critical Review on Paras-Pipal (Thespasia Populnea Linn)
}

\section{“An Ayurvedic Herb”}

\section{Pamnani $\mathbf{M}^{1}$, Kumar $\mathbf{V}^{2}$, Kaushal $\mathrm{K}^{3}$, Sharma $\mathrm{AK}^{4}$, Mishra $\mathrm{RC}^{5}$ and Soni P6 \\ PG Department of dravyaguna vijnana, MMM Govt. Ayurveda college, India}

*Corresponding Author: Dr. Manish Pamnani, PG Department of dravyaguna vijnana, MMM Govt. Ayurveda college, Udaipur, Rajasthan, India, Tel: 8619919854/ 9413173037; Email: manishpamnani007@gmail.com

\section{Abstract}

Herbs play a major role in Ayurvedic system. An ayurvedic herb is a plant source which is used in the preparation of ayurvedic medicines. It acts as a perfect mechanism in bringing a balanced harmony between the mind \& spirit. The ayurvedic science which works based on the herb promises wonders to mankind when taken in a wise \& prudent manner. Paraspipal is one of them. Paraspipal (Thespesia populnea) also known as Parisha a drug of Panchvalkala (Mishrak Gana) is a plant that occurs in India specially in seacoastal regions.It is commonly planted as an avenue tree \& at other places largely cultivated for ornament \& shade. It is attributed with Kaphkara, Shukrala, Grahi \& Mutrasangrahniya Karmas. Present review article analyze the classical references \& medicinal uses on the basis of various available texts.

Keywords: Ayurveda; Grahi; Mutrasangrahniya; Paraspipal; Panchvalkala

\section{Introduction}

Paraspipal or Parisha enumerated with Panchvalkala by Acharya Bhavmishra \& also known as Indian Tulip tree, Pacific rosewood or Portia tree. It is a species of flowering plant in the Mallow family, Malvaceae. It is a small tree or arborescent shrub that has a pan tropical distribution, found on coasts around the world. In India it extends from the shoves of west Bengal to Peninsular India \& the Andamans. Also grown as a road side tree in tropical regions. It applies externally to various skin diseases eg. psoriasis \& also acts as atonic, astringent also used in diseases like urinary tract infections, diabetes, arthritis, asthma, Gunea worm infections. It posses profound therapeutically potency attributed with Kaphkara, Shukrala, Grahi \& Mutrasangrahniya Karmas $[1,3,5]$.

\section{Chief Characters}

A small to medium sized tree with roundish or ovate, cordate, acuminate, entire glabrous leaves $7-12 \mathrm{~cm}$ with long petioled [2].

Fruit: Conical to spindle shaped \& fruiting occurs particularly in Dec-april. 


\section{Journal of Natural \& Ayurvedic Medicine}

Flowers: Yellow with red spots \& flowering occurs throughout the year.

\section{Etymology}

- Parisha-'Paari Brahmagyanama'

- Isha-Ishayte gamyate asmin zigiushbhi iti.

- People for enlightment wish to prefer this tree.

- Thespasia-Thespesios(Greek)-wonderful.

- Populnea-Populas(Latin)-pertaining to populars $[3,6]$.

\begin{tabular}{|c|c|}
\hline \multirow{4}{*}{ Gardhbhaand } & $\begin{array}{l}\text { 'Gardbhasya andamiv falam asya iti } \\
\text { gardhbhaand' }\end{array}$ \\
\hline & $\begin{array}{l}\text { Its fruit resembles like testis of an } \\
\text { ass,due to this characteristic it is } \\
\text { known as Gardhbhaand. }\end{array}$ \\
\hline & $\begin{array}{l}\text { 'Gardhbh gandh vishesham,amti } \\
\text { prapnoti,am gatyadishyu' }\end{array}$ \\
\hline & It have specific smell. \\
\hline Kandraala & $\begin{array}{l}\text { Is tree mostly found in caves or caves } \\
\text { like places known as Kandraala. }\end{array}$ \\
\hline \multirow{4}{*}{ Kapitana } & Kam pitayati kapitana \\
\hline & Kapi stanoti vaa \\
\hline & $\begin{array}{l}\text { Kapina kape vaa varnasya shobha } \\
\text { tanute iti }\end{array}$ \\
\hline & $\begin{array}{l}\text { Kapitana expands beauty as like as } \\
\text { colour of monkey }\end{array}$ \\
\hline Suparshvaka & Trees spread in an arranged manner. \\
\hline Cheerpadapa & Fruit consists of latex. \\
\hline Falisha & Trees have Fruits. \\
\hline Kamandal & $\begin{array}{l}\text { Fruit resembles like kamandal(Thing } \\
\text { used to kept water or any other liquid) }\end{array}$ \\
\hline Suprititishta & Trees are famous. \\
\hline Kapichoot & Monkeys like its fruits as mango. \\
\hline Falashrenivara & $\begin{array}{l}\text { Its fruits are best among the } \\
\text { Panchcheeri Vriksha. }\end{array}$ \\
\hline Kapervaas & $\begin{array}{l}\text { Mostly monkeys like to live on these } \\
\text { trees so it is called as Kapervaas }\end{array}$ \\
\hline
\end{tabular}

Table 1: Showing the Synonyms according to the various classical texts [6,7].

\begin{tabular}{|c|c|}
\hline Language & Names \\
\hline English & $\begin{array}{c}\text { Annadine, Bendy tree, Bhendi tree, Indian } \\
\text { Tulip tree, Portia tree. }\end{array}$ \\
\hline Hindi & Bhendhi, Gajadanda, Paraspipal, Parasipu \\
\hline Malayalam & Poovarasu, Chelantipatta, pooparutti \\
\hline Bengali & Gajashundi, Palaspipal, Poresh \\
\hline Gujarati & Paras Piplo \\
\hline Kannada & Arasi, Bangali, Huvarasi \\
\hline \multirow{2}{*}{ Marathi } & Aastha, Aas, Parasbhendi, Parosapimpal, \\
\cline { 2 - 2 } & Parshvapimpal, Pimparani, Pimpari. \\
\hline Tamil & Puvarsu \\
\hline Telgu & Gangaravi \\
\hline Sanskrit & $\begin{array}{c}\text { Paarish, Gardhbhanda, Kandrala, Kapitana, } \\
\text { Suparshvaka }\end{array}$ \\
\hline
\end{tabular}

Table 2: Showing the Vernacular Names according to the various classical texts [8].

\begin{tabular}{|c|c|}
\hline Samhitas/Nighantu & Gana/Varg \\
\hline Charaka Samhita & $\begin{array}{c}\text { Mutrasangrahniya, } \\
\text { Kashayaskandha }\end{array}$ \\
\hline Sushruta Samhita & Nyagrodhadi Gana \\
\hline $\begin{array}{c}\text { Bhaav Prakash } \\
\text { Nighantu }\end{array}$ & Vatadi Varg \\
\hline Kaidev $\backslash$ Nighantu & Aushadhi Varg \\
\hline Shaaligram Nighantu & Vatadi Varg \\
\hline Ashtanga Nighantu & Nyagrodhadi Gana \\
\hline
\end{tabular}

Table 3: Showing the Gana/Varg according to the various classical texts [9-14].

\begin{tabular}{|c|c|c|c|c|c|}
\hline \multicolumn{7}{|c|}{ RASA } \\
\hline Rasa & P.v.sharma & B.N. & K.N. & N.R. & P.N. \\
\hline Madhura & - & $\begin{array}{c}+(\text { Root \& } \\
\text { Majja })\end{array}$ & $\begin{array}{c}+(\text { Root \& } \\
\text { Majja })\end{array}$ & $\begin{array}{c}+(\text { Fala, } \\
\text { Majja) }\end{array}$ & - \\
\hline Amla & - & $+($ Fala $)$ & $+($ Fala $)$ & $+($ Fala $)$ & - \\
\hline Lavana & - & - & - & - & - \\
\hline Katu & - & - & - & - & - \\
\hline Tikta & - & - & - & - & - \\
\hline Kashaya & + & $+($ Majja $)$ & + (Majja) & + (Root) & + \\
\hline
\end{tabular}

\begin{tabular}{|c|c|c|c|c|c|c|}
\hline \multicolumn{5}{|c|}{ GUNA } & \\
\hline Guna & P.v. sharma & B.N. & K.N. & N.R. & P.N. & M.N. \\
\hline Laghoo & + & - & - & - & - & - \\
\hline Ruksha & + & - & - & - & + & - \\
\hline Snigdha & - & + & + & + & - & + \\
\hline Sheet & - & - & - & - & + & - \\
\hline
\end{tabular}

Table 4: Showing the Rasa Panchaka according to the various classical texts [11,12,15-17]. 


\section{Journal of Natural \& Ayurvedic Medicine}

\begin{tabular}{|c|c|c|c|c|c|c|c|}
\hline Doshkarma & S.S. & M.N. & S.N. & N.R & B.N. & K.N. & P.V. sharma \\
\hline Kaphakaraka & - & + & + & + & + & + & - \\
\hline Vatpittashamana & - & - & - & + & - & - & - \\
\hline Kaphapittashamana & - & - & - & - & - & - & + \\
\hline Raktpittashamaka & + & - & - & - & - & - & - \\
\hline
\end{tabular}

Table 5: Showing the Doshkarma according to the various classical texts $[10-12,15,16,18,19]$.

Veerya-Sheet(P.V),Vipaka-Katu(P.V)

\begin{tabular}{|c|c|c|c|c|c|c|c|c|}
\hline Karma & M.N. & S.N. & N.R. & B.N. & K.N. & P.v.sharma & S.S & C.S. \\
\hline Vrishya & + & + & + & + & + & - & - & - \\
\hline Krimiprada(krimikaraka) & + & + & + & + & + & - & - & - \\
\hline Hridya & - & - & + & - & - & + & - & - \\
\hline Dahashamaka & - & - & + & - & - & - & + & - \\
\hline Kanthya & - & - & + & - & - & - & - & - \\
\hline Kushthghana & - & - & - & - & - & + & - & - \\
\hline Yonidoshhara & - & - & - & - & - & + & - & - \\
\hline Vranaropana & - & - & - & - & - & + & - & - \\
\hline Punsavana & - & - & - & - & - & + & - & - \\
\hline Mutrasangrahniya & - & - & - & - & - & + & - & + \\
\hline Vranropana & - & - & - & - & - & - & + & - \\
\hline Graahi & - & - & - & - & - & + & + & - \\
\hline Bhagna-Asthisandhana & - & - & - & - & - & - & + & - \\
\hline Medohara & - & - & - & - & - & + & + & - \\
\hline Vishaghana & - & - & - & - & - & + & - & - \\
\hline Yonidoshhara & - & - & - & - & - & - & + & - \\
\hline
\end{tabular}

Table 6: Showing the Karmas (pharmacological actions) according to the various classical texts $[9-12,15,16,18,19]$.

\section{Chemical Composition}

The Plant yields kaempferol \& its glycosides, herbacetin \& its glycosides, populenol, populnin, populnetin, quercetin, rutin, gossipetin, gossypol, Bsitosterol \& its glycoside, lupeol, lupenone, alkanes, myricylalcohol, thespesone, thespone, calycopterin, sesquiterpenoidal, quinones, aminoacids \& carbohydrates. Fatty acid composition of the seed oil is also reported [5].

\section{Folklore Uses}

- In Middle Province its Root considers as Balya.

- People of konkan region uses its flowers in PAMA disease \& using its leaves(after heated)in inflammation or other inflammatory body places.

- People also use its stem bark decoction for washing of PAMA affected areas.

- In Maurities its bark uses as a purifier also in diseases like diarrohea, bleeding piles etc.

- In Medagascar its bark decoction used in chronic diarrhea and various skin diseases.
- Rumphians people uses its inner wood in a disease named as Pleurodynia in which severe pain occurs in ribs \& also person feels difficulty to take breath.

- In Koman its leaves are used as ointment to cure eczema of childrens.

- In Philippians its bark decoction used in bleeding diarrohea.

- In Dahiti its fruits are used to cure headache $[7,20]$.

\section{Controversy}

Pareesha (Thespesia populnea)is included in Panchcheeri vriksha. (A group of trees which cosists of latex.)it's bark doesn't cosists of latex but its fruits have latex \& also included in Panch -valkala mishrak gana. Pareesha is a synonym of Paraspipal. Some authors considers F.arnottiana \& F.rumphi as Pareesha because their leaves resembles like as pippal(Ficus religiosa) [11].

\section{Part Used}

Stem bark $[3,15]$. 


\section{Journal of Natural \& Ayurvedic Medicine}

\section{Posology}

Decoction- 50-100ml, POWDER-3-6gm [3,11,15].

\section{Latest Research on Thespasia Populnea}

- Antidiabetic and Antihyperlipidemic effect of Thespasia populnea fruit pulp.

- Anti-psoriatic activity.

- Antibacterial activity.

- Antimicrobial property of Thespasia populnea [21,22].

\section{Therapeutic Uses}

- Applied externally to Scabies, Psoriasis \& other skin diseases.

- Its unripe fruit with Misri or Guda in tablet form through oral route to cure Aam, Sangrahini, Arsha.

- Seed oil is used in various skin diseases.

- Its extract is used in Pitta diseases.

- Its 2 to 3 seed with Shakkar used to cure Sangrahini, bavasira (piles), Sujaka, Burning micturition.

- Its fruit, leaves, root used to cure skin diseases when applied externally.

- Its yellow liquid which comes out from fruit used to cure skin diseases when applied externally, before using it, the affected area should be washed with its bark decoction properly.

- Its bark decoction used to cure abdominal pain.

- After heating leaves \& convert into paste then applies externally to the swelling of joints,gall bladder, it helps to relieve them.

- Its decoction used to purify the blood when taken in a dose of 7-10 Tola $[2,3,7,20]$.

\section{Therapeutic Indications}

Kushta, Yonidosha, Prameha, Vrana, Bleeding disorders, Hridroga, Kanthruja [2,3,15].

\section{Discussion}

It is attributed with Kaphakara, Shukrala, Grahi, and Mutrasangrahniya Karmas. A drug of Panchvalkala/ Panchcheeri Vriksha. It is indicated in Kapha-Pitta vikara,Kushta (skin diseases), Yonidosha (vaginal disorders), Prameha (Diabetes), Vrana \& other Bleeding disorders. It is considered useful in toxicity \& Medoroga due to its Lekhana property. Acharya Bhavprakash says it shows Punsavana activity when Woman regularly takes Paraspippal mixed with Jeeraka \& Sharpunkha to have male child. Most of the classical authors says that it have Vrishya property. Its Fruits resembles like Testis of an ass due to this character it is known as Gardhbhanda. Its fruit also consists of latex used to cure skin diseases when applied externally. Its leaves in the form of hot poultice beneficial in painful joints act as a tonic, astringent \& given internally as an alternative.

\section{Conclusion}

Paraspippal a drug of Panchcheeri/ Panchavalkala mishraka gana does Grahi, Mutrasangrahniya actions due to Kashaya rasa (astringent property) used in skin diseases when applied externally \& indicated in Prahmeha disorder (a group of 20 diseases, Madhumeha (Diabetes) is one of them) according to the ancient ayurvedic acharya. Regarding it we can use it in diabetes in which frequent urination \& skin diseases occurs. More research has to be needed.

Plant rich in chemical constituent \& posses many medicinal properties. It also helpful in skin diseases because it consists Madhura rasa which has Twachya property as per Acharya charaka means that it is useful in skin disorders also consists Kashaya rasa which diminishes the Rakta \& Pitta dosha which play a major role in skin diseases. More research has to be needed.

\section{References}

1. Significance of Ayurvedic Herbs.

2. Ojha JK, A handbook of Dravyaguna. Chaukhamba publications, pp: 253.

3. Niteshwar K Hemadri K, Dravyaguna vijnana, Chaukhamba publications pp: 227.

4. Asima Chatterjee, Pakrashi SC, The treatise of indian medicinal plants 5: 188.

5. Sanjeev kumar laale, Aushadhnaamrupavigyanam, part-1, pp: 178.

6. Bapalal vaidhya SH, Nighantu Adarsha, Chaukhamba Bharti Academy 1:167.

7. Thespesia populnea Portia Tree.

8. Agnivesa, Kasinath Sastri Pt, Gorakhanatha Chaturvedi, Charaka Samhita. Revised by Charaka, Drdhabala, Chaukhamba Bharati Academy, Varanasi, Re-print 2004.

9. Sushrutha, Sushrutha Samhita, Ayurveda-tattvasandipika In: Kaviraja ambikadutta shastri (Ed.), Part -1, Chaukhambha Sanskrit Sansthan, Varanasi. 


\section{Journal of Natural \& Ayurvedic Medicine}

10. Chunekar KC, Sri Bhavamisra Bhavaprakasha Nighantu, In: Pandeya GS (Ed.), Chaukhamba Bharti Academy.

11. Acharya Kaiyadeva (1979) Kaiyadeva Nighantu (Pathyapathya Vibhodhaka). In: Priya Vrat Sharma (Ed), $1^{\text {st }}$ (Edn), Guru Prasada Sharma, Chaukhambha Orientalia Varanasi.

12. Shaligrama (2007) Shaligrama Nighantu. Khemraj Shrikrishna Das Mumbai pp: 492-493.

13. Vahata (1973) Astanga Nighantu. Sharma PV (Ed), $1^{\text {st }}$ (Edn), Kuppuswamy Shastri Research Institute, Madras.

14. Sharma Priya Vrat, Dravyaguna Vijnana. Chaukhambha Bharati Academy, Varanasi Re-print $20112: 680$.

15. Krushnashastri N, Pandurang J (1936) Nighantu Ratnakar. Saraswati Pustakalaya, Kanpur.

16. Sharma Priya Vrat (2004) Priyanighantu. Along with the author's Hindi commentary. Padma (Ed),
Varanasi, Chaukhamba Surabharathi Prakashana, Chapter 1, Haritakyadivarga, pp: 275.

17. Nrupa Madanpala (1961) Madanpala nighantu (Eds.), Gangavishnu Srikrishnadas pp: 120

18. Gyanendra Pandey, Shodhala nighantuh (Eds.), Dwivedi RR, Chaukhamba Krishnadas Academy, Varanasi PP: 113.

19. Shreechandra raj bhandari (1953) Vanaushdhi chandrodya. 2nd (Edn.), Chaukhambha Sanskrit Sansthan, Varanasi, pp: 63-64.

20. JLN Shastry, Thespesia Populnea- Portia Trees, Illustrated Dravyaguna Vijnana.

21. Senthil-Rajan D, Rajkumar M, Srinivasan R, Kumarappan C, Arunkumar K, et al. (2013) Investigation on antimicrobial activity of root extracts of Thespesia populnea Linn. Trop Biomed 30(4): 570578. 